\title{
Comparative trial of manual and mechanical percussion technique with gravity-assisted bronchial drainage in patients with cystic fibrosis
}

\author{
MAUREEN MAXWELL AND AILEEN REDMOND \\ Royal Belfast Hospital for Sick Children
}

SUMMARY Chest physiotherapy still remains one of the most important aspects in the treatment of chest complications of cystic fibrosis. A mechanical device that allows the patient with cystic fibrosis to do his own chest physiotherapy will be of great benefit if it is as effective as manual percussion. 14 patients with cystic fibrosis using mechanical and manual percussion physiotherapy were studied by measuring sputum volumes, and FEV and FVC. Results with the mechanical percussor were as good as with the manual percussor and, therefore, it would be reasonable for the older patient to use the former on his own.

The life expectancy of patients with cystic fibrosis (CF) has greatly improved in recent years (Anderson and Goodchild, 1976), and most CF clinics are now having to extend their care to the adolescent and young adult. Any patient, as he grows older, resents having to depend on another adult for chest physiotherapy. We have, therefore, compared the use of manual with mechanical percussion as the latter would enable the patient to do his own treatment and thus gain independence (Denton, 1962).

\section{Patients and method}

14 patients with CF between ages 7 and 21 years who could co-operate with the use of the Vitalograph spirometer were chosen. At the time of testing the patients were in clinical remission. 11 were normally sputum producers and 3 produced sputum only when they had exacerbations of chest infection.

Apparatus. The mechanical percussion unit, EquiMed percussor* (Fig. 1) operates on 230 volts at 200-3200 strokes/min using a 10-speed selector switch. All the children were tested using 230 strokes $/ \mathrm{min}$. The percussor weighs $1.588 \mathrm{~kg}$. The

*Obtainable from Medical and Scientific Computer Services Ltd, Altona Road, Lisburn, Co. Antrim, N. Ireland.

Royal Belfast Hospital for Sick Children AILEEN REDMOND, consultant paediatrician

Faculty of Social and Health Sciences, School of Physiotherapy, Northern Ireland Polytechnic, Belfast MAUREEN MAXWELL, lecturer in physiotherapy unit is applied to the chest wall, the percussor head being directly in contact with the rib cage (Fig. 2) over the selected segment of the lung to be drained.

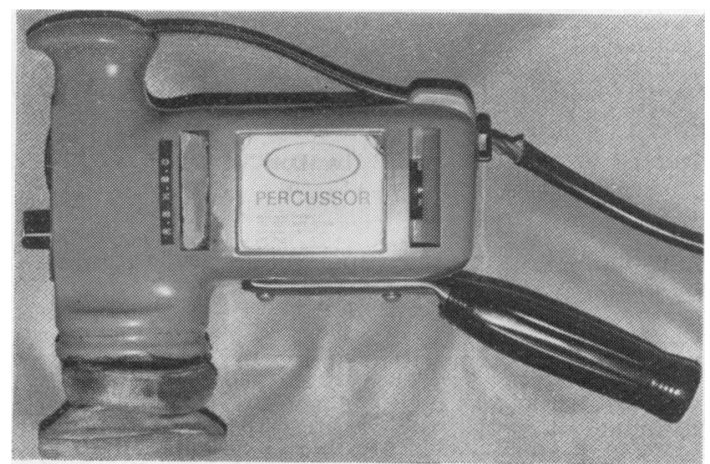

Fig. 1 Equi-Med percussor.

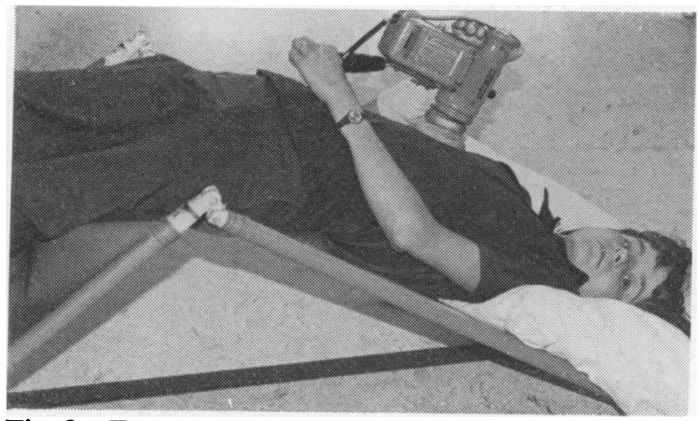

Fig. 2 Teenage patient using the percussor. 
The percussion was interrupted only for expectoration and change of position.

Experimental conditions. Patients were treated on one day with manual and the next with mechanical percussion, random sampling tables being used to determine the initial method. Each patient was treated at the same time each day. The Vitalograph readings were FEV, FVC, FER, the readings being taken at 10-min intervals for one hour after treatment. Amounts of sputum were measured by weight.

The postural drainage positions were those described by Kendig and Chernick (1977).

\section{Lower lobes}

Four segments, right and left, anterior, posterior, lateral, superior.

\section{Middle and lingular lobes}

Upper lobes

Two segments, right and left, anterior, apical, using a treatment time of $\mathbf{3 2}$ minutes for each period.
The various lobes were treated in the same order in each patient and all segments were treated for a period of 2 minutes.

Table 3 Amount of sputum in 14 patients after manual and mechanical chest percussion

\begin{tabular}{|c|c|c|c|}
\hline \multirow[t]{2}{*}{ Case } & \multirow{2}{*}{$\begin{array}{l}\text { Age } \\
\text { (years) }\end{array}$} & \multicolumn{2}{|c|}{ Amount of sputum $(\mathrm{g})$} \\
\hline & & Manual & Mechanical \\
\hline 1 & $9 \frac{1}{2}$ & $8 \cdot 51$ & $15 \cdot 42$ \\
\hline 2 & $8 \frac{2}{2}$ & 23.06 & 27.46 \\
\hline 3 & $14 t^{2}$ & 18.54 & 8.09 \\
\hline 4 & $12 \frac{1}{4}$ & 12.68 & $3 \cdot 38$ \\
\hline 5 & $12 \frac{1}{2}$ & $18 \cdot 54$ & 8.09 \\
\hline 6 & 12 & - & - \\
\hline 7 & $7 \frac{1}{8}$ & 0.856 & 0.778 \\
\hline 8 & $6 \pm$ & 1.55 & 1.33 \\
\hline 9 & $20 \frac{1}{2}$ & 20.34 & $32 \cdot 26$ \\
\hline 10 & $21^{2}$ & 1.81 & 0.71 \\
\hline 11 & 7 & 1.5297 & 1.7137 \\
\hline 12 & 7 & - & - \\
\hline 13 & $14 t$ & - & - \\
\hline 14 & $8 \frac{1}{2}$ & 25.66 (vomit) & 8.8413 \\
\hline
\end{tabular}

Table 1 FEV 1 results (in litres) in 14 patients using manual and mechanical percussion

\begin{tabular}{|c|c|c|c|c|c|c|c|}
\hline \multirow[t]{2}{*}{ Case } & \multirow{2}{*}{$\begin{array}{l}\text { Age } \\
\text { (years) }\end{array}$} & \multicolumn{3}{|l|}{ Manual } & \multicolumn{3}{|c|}{ Mechanical } \\
\hline & & Before & $+10 \min$ & $+60 \mathrm{~min}$ & Before & $+10 \min$ & $+60 \min$ \\
\hline $\begin{array}{r}1 \\
2 \\
3 \\
4 \\
5 \\
6 \\
7 \\
8 \\
9 \\
10 \\
11 \\
12 \\
13 \\
14\end{array}$ & $\begin{array}{c}9 \frac{1}{2} \\
8 \frac{1}{2} \\
14 \frac{1}{2} \\
12 \frac{8}{4} \\
12 \frac{1}{2} \\
12 \\
7 \frac{1}{2} \\
6 \frac{1}{2} \\
20 \frac{1}{2} \\
21 \\
7 \\
7 \\
14 \frac{1}{2} \\
8 \frac{1}{2}\end{array}$ & $\begin{array}{l}1.55 \\
0.85 \\
1.8 \\
1.30 \\
1.20 \\
1.65 \\
0.45 \\
0.55 \\
0.82 \\
2.85 \\
0.50 \\
1.75 \\
0.55 \\
1.25\end{array}$ & $\begin{array}{l}1.50 \\
0.70 \\
1.63 \\
1.25 \\
0.84 \\
1.42 \\
0.55 \\
0.40 \\
0.74 \\
2.92 \\
0.51 \\
1.65 \\
0.44 \\
1.34\end{array}$ & $\begin{array}{l}1.75 \\
0.85 \\
1.80 \\
0.74 \\
1.15 \\
1.34 \\
0.65 \\
0.54 \\
0.77 \\
2.05 \\
0.50 \\
1.60 \\
0.40 \\
1.15\end{array}$ & $\begin{array}{l}1.35 \\
0.85 \\
1.95 \\
0.72 \\
1.1 \\
1.60 \\
0.45 \\
0.45 \\
0.81 \\
1.90 \\
0.56 \\
1.63 \\
0.6 \\
0.98\end{array}$ & $\begin{array}{l}1.50 \\
0.77 \\
1.55 \\
0.80 \\
1.15 \\
1.39 \\
0.45 \\
0.42 \\
0.75 \\
2.45 \\
0.45 \\
1.73 \\
0.60 \\
0.95\end{array}$ & $\begin{array}{l}1.75 \\
0.90 \\
1.69 \\
0.86 \\
0.98 \\
1.20 \\
0.51 \\
0.43 \\
0.80 \\
2.80 \\
0.48 \\
1.70 \\
0.75 \\
1.50 \\
\end{array}$ \\
\hline
\end{tabular}

Table 2 FVC results in litres in 14 patients using manual and mechanical percussion

\begin{tabular}{|c|c|c|c|c|c|c|c|}
\hline \multirow[t]{2}{*}{ Case } & \multirow{2}{*}{$\begin{array}{l}\text { Age } \\
\text { (years) }\end{array}$} & \multicolumn{3}{|l|}{ Manual } & \multicolumn{3}{|c|}{ Mechanical } \\
\hline & & Before & $+10 \min$ & $+60 \mathrm{~min}$ & Before & $+10 \min$ & $+60 \min$ \\
\hline $\begin{array}{r}1 \\
2 \\
3 \\
4 \\
5 \\
6 \\
7 \\
8 \\
9 \\
10 \\
11 \\
12 \\
13 \\
14\end{array}$ & $\begin{array}{c}9 \frac{1}{2} \\
8 \frac{1}{2} \\
14 \frac{1}{4} \\
12 \frac{4}{4} \\
12 \frac{1}{2} \\
12 \\
7 \frac{1}{2} \\
6 \frac{1}{4} \\
20 \frac{1}{2} \\
21 \\
7 \\
7 \\
14 \frac{1}{2} \\
8 \frac{1}{2}\end{array}$ & $\begin{array}{l}2 \cdot 15 \\
1 \cdot 0 \\
2 \cdot 30 \\
1 \cdot 30 \\
1 \cdot 65 \\
2 \cdot 10 \\
0 \cdot 07 \\
1 \cdot 15 \\
1 \cdot 86 \\
4 \cdot 52 \\
1.00 \\
2 \cdot 05 \\
1 \cdot 25 \\
1 \cdot 95\end{array}$ & $\begin{array}{l}2 \cdot 10 \\
0 \cdot 90 \\
2 \cdot 20 \\
1 \cdot 25 \\
1 \cdot 56 \\
2 \cdot 00 \\
0 \cdot 75 \\
1 \cdot 15 \\
1 \cdot 70 \\
4 \cdot 80 \\
1 \cdot 00 \\
2 \cdot 09 \\
1 \cdot 00 \\
1 \cdot 80\end{array}$ & $\begin{array}{l}2 \cdot 40 \\
1 \cdot 20 \\
2 \cdot 30 \\
1 \cdot 33 \\
1 \cdot 75 \\
2 \cdot 06 \\
0 \cdot 90 \\
1 \cdot 30 \\
1 \cdot 82 \\
4 \cdot 45 \\
0 \cdot 88 \\
1 \cdot 95 \\
1 \cdot 10 \\
1 \cdot 75\end{array}$ & $\begin{array}{l}1 \cdot 85 \\
1 \cdot 15 \\
2 \cdot 50 \\
1 \cdot 35 \\
1 \cdot 70 \\
2 \cdot 20 \\
0 \cdot 72 \\
1 \cdot 20 \\
1 \cdot 86 \\
4 \cdot 50 \\
1 \cdot 10 \\
1 \cdot 96 \\
1 \cdot 45 \\
1 \cdot 80\end{array}$ & $\begin{array}{l}2 \cdot 10 \\
1 \cdot 06 \\
2 \cdot 15 \\
1.40 \\
1 \cdot 95 \\
2 \cdot 00 \\
0 \cdot 55 \\
1 \cdot 19 \\
1 \cdot 67 \\
4 \cdot 4 \\
0.90 \\
2.05 \\
1 \cdot 53 \\
1 \cdot 80\end{array}$ & $\begin{array}{l}2.30 \\
1.25 \\
2.20 \\
1.48 \\
1.80 \\
1.85 \\
0.70 \\
1 \cdot 15 \\
1.75 \\
4.60 \\
1.25 \\
1.98 \\
1.53 \\
2.05\end{array}$ \\
\hline
\end{tabular}




\section{Results}

The FEV (Table 1) and FVC data (Table 2) show there was no obvious difference between mechanical and manual treatment, and this was confirmed by statistical analysis. Amounts of sputum are shown in Table 3. It was suggested by the parents that the children coughed up more sputum when using the mechanical percussor at home but, when the actual amounts were measured, there was no overall difference.

\section{Discussion}

All patients and all parents (with the exception of one) preferred mechanical percussion. Patients found it was less tiring and that it gave them a sense of support. Most parents admitted that they felt that they could not do the manual technique as well as the trained physiotherapist and felt the children were not gaining maximum benefit. However, they thought the children received maximum benefit with the mechanical percussor. All patients could treat some segments themselves, particularly the upper lobes. The main disadvantage for the patient was the noise of the percussor. We find that small babies adjust to the mechanical percussor and often fall asleep during treatment. The youngest child who could use the percussor independently was 13 years. Small children could not reach the basal segments of the lower lobes and found the middle lobe difficult, although they could treat the upper ones.
It would appear that mechanical is as effective as manual percussion. The percussor costs about $£ 85$ (plus VAT). This is a large sum to spend, particularly as manual percussion can be just as effective. The main advantage of a mechanical percussion unit is that a teenage or adult CF patient can use it entirely on his or her own and thus be independent.

We thank Dr Tom Hassard, Department of Medical Statistics, Queen's University, Belfast, and Dr F. Stanford, Consultant Chest Physician, Belfast City Hospital.

\section{References}

Anderson, C. M., and Goodchild, M. C. (1976). Cystic Fibrosis. Manual of Diagnosis and Management, pp. 120-122. Blackwell: Oxford.

Denton, R. (1962). Bronchial secretions in cystic fibrosisthe effects of treatment with mechanical percussion vibration. American Review of Respiratory Diseases, 86, 41-46.

Kendig, E. L., and Chernick, V. (1977). Diagnostic and therapeutic procedures. In Disorders of the Respiratory Tract in Children, third edition, pp. 114-119. Edited by W. Waring. Saunders: Philadelphia.

Correspondence to Dr A. O. B. Redmond, Royal Belfast Hospital for Sick Children, 180 Falls Road, Belfast BT12 6BE.

Received 27 November 1978 